\title{
Aripiprazole: the evidence of its therapeutic impact in schizophrenia
}

\author{
William Winlow, Louise Profit, Paul Chrisp \\ Core Medical Publishing, Knutsford, UK
}

\begin{abstract}
Introduction: An ideal antipsychotic would rapidly stabilize acute psychotic symptoms and maintain the patient, without relapse, for prolonged periods in the absence of extrapyramidal, endocrine, diabetic, or cardiovascular side effects, and without weight gain. The dopamine partial agonist aripiprazole is compared with this ideal and with conventional antipsychotics, such as haloperidol, and with atypical antipsychotics.
\end{abstract}

Aims: To review the evidence for the clinical impact of aripiprazole in the treatment of patients with schizophrenia.

Evidence review: There is clear evidence that aripiprazole is as effective as haloperidol in reducing the positive and negative symptoms of schizophrenia and schizoaffective disorder. In patients with schizophrenia, aripiprazole has been shown to stabilize acute psychotic symptoms, prevent relapse in stabilized patients, and maintain patients with schizophrenia following acute relapse. Furthermore, in common with other atypical antipsychotics, aripiprazole appears to be associated with a lower incidence of side effects than typical antipsychotics and may reduce discontinuation of drug therapy. Evidence also suggests that aripiprazole may be associated with a lower incidence of extrapyramidal symptoms than conventional antipsychotics, but further long-term studies concerning tardive dyskinesia are required. Studies on the cost effectiveness of aripiprazole, as well as the quality of life and general functioning of patients taking the drug are still required, although there is some evidence of improved quality of life. Further evidence comparing aripiprazole with other atypical antipsychotics would be welcome.

Clinical value: In conclusion, aripiprazole is an atypical antipsychotic suitable for first-line use in patients with schizophrenia. Its clinical value in relation to other atypical antipsychotics remains to be elucidated.

Key words: aripiprazole, clinical impact, evidence, schizophrenia, treatment

Core evidence clinical impact summary for aripiprazole in schizophrenia

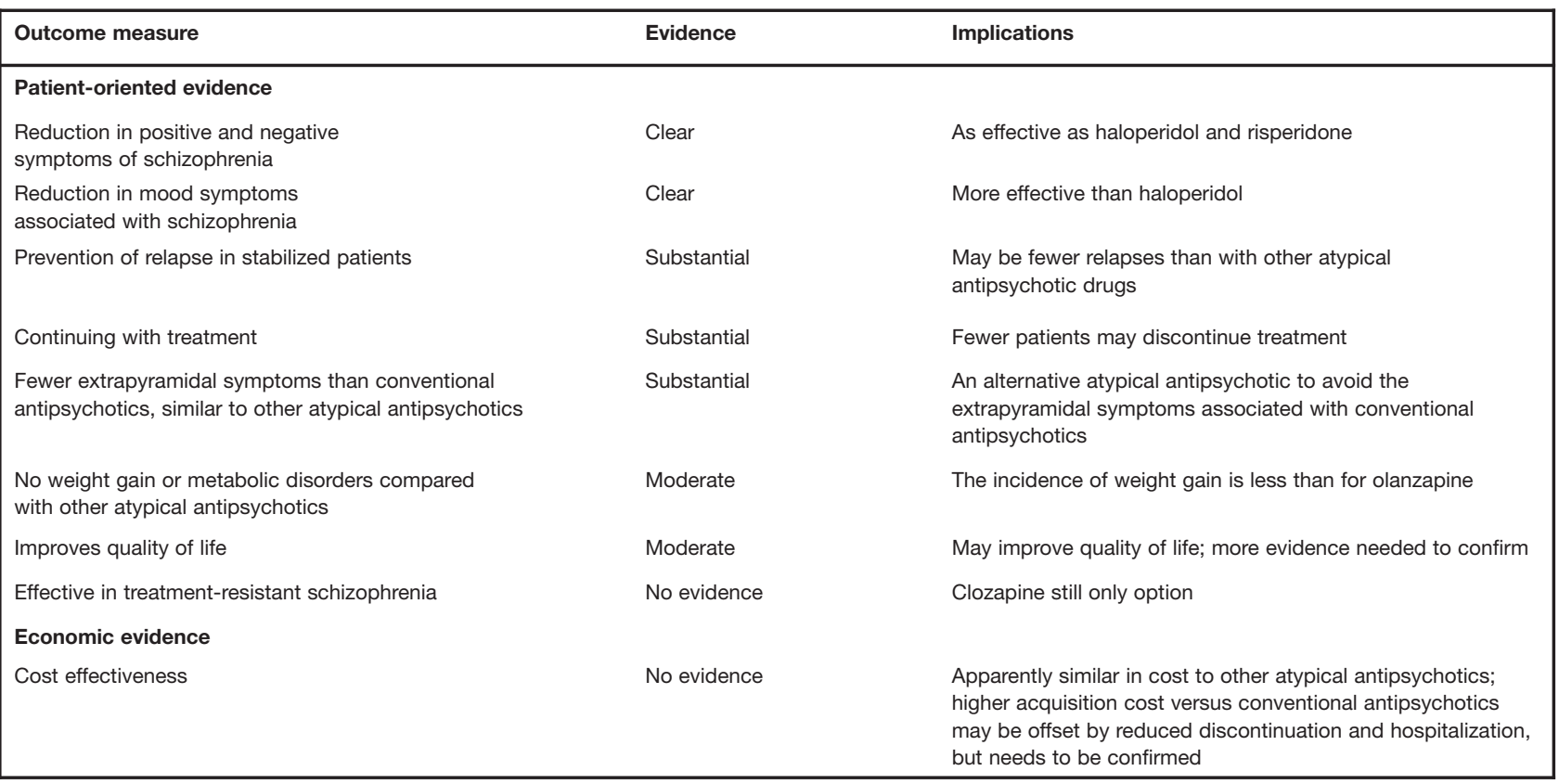




\section{Scope, aims, and objectives}

Patients with schizophrenia are often severely debilitated with disturbed behavior patterns. Currently both atypical and conventional antipsychotic drugs are used in their treatment. Atypical antipsychotics are less likely to cause extrapyramidal symptoms than the conventional antipsychotics. Aytpical antipsychotics, however, may cause weight gain and the development of metabolic syndrome and diabetes mellitus, and have been associated with hyperprolactinemia and QTC prolongation (Lieberman 2004; Lublin et al. 2005).

The objective of this review is to assess the clinical impact of the atypical antipsychotic aripiprazole in the treatment and clinical management of patients with schizophrenia.

\section{Methods}

English language searches were conducted on March 31, 2005 and April 1, 2005 using the search terms: "aripiprazole," "abilify," "aripiprazole AND schizophrenia," and "aripiprazole, schizophrenia AND clinical trials." The following sources were searched:

- PubMed, www.ncbi.nlm.gov/entrez, 1966 to date

- Database of Abstracts of Reviews of Effects (DARE), National Health Service (NHS) Economic Evaluation Database (NHSEED), Health Technology Assessment (HTA), www.york.ac.uk/inst/crd/darehp.htm. All three databases were searched together. All fields searched

- National Guideline Clearinghouse, www.guideline.gov

- National Institute for Health and Clinical Excellence (NICE), www.nice.org.uk

- Cochrane Database of Systematic Reviews (CDSR), www.cochrane.org/index0.htm. Entire site searched

- Clinical Evidence (BMJ), www.clinicalevidence.com

- Clinical trial registries, www.clinicaltrials.gov, www.clinicalstudyresults.org

Continuing automatic searches were carried out through the National Center for Biotechnology Information (NCBI) until July 19, 2005. A total of 208 articles were retrieved and screened for relevance (Table 1). Review articles, correspondence, duplicate publications, and articles not directly related to aripiprazole in schizophrenia or schizoaffective disorder were excluded from the analysis. Two additional studies were revealed following handsearching. For each outcome, preference was given to level 1 and level 2 evidence.

A further search of the English language literature on PubMed using the search terms "aripiprazole," "clinical trial," "meta analysis," "randomized controlled trial," "review," and "humans" was conducted with the date limits April 1, 2005 to March 22,
Table 1 | Evidence base included in the review

\begin{tabular}{|c|c|c|}
\hline \multirow[t]{2}{*}{ Category } & \multicolumn{2}{|c|}{ Number of records } \\
\hline & Full papers & Abstracts \\
\hline Initial search & 208 & 10 \\
\hline records excluded & 197 & 9 \\
\hline records included & 11 & 1 \\
\hline Additional studies identified & 5 & 3 \\
\hline Level 1 clinical evidence & 3 & 0 \\
\hline Level 2 clinical evidence & 9 & 1 \\
\hline Level $\geq 3$ clinical evidence & 1 & 3 \\
\hline trials other than RCT & 1 & \\
\hline case reports & 1 & \\
\hline Economic evidence & 1 & 0 \\
\hline
\end{tabular}

2006. The limits were imposed to provide specificity to the search. Twenty-six records were found, of which two were included in the analysis under "additional studies." Exclusion criteria were the same as those used in the initial literature searches. A further trial was revealed manually in this second literature search and was included in the analysis.

\section{Disease overview}

\section{Characteristics of schizophrenia}

Schizophrenia is primarily a neurologic disorder externally observed as disturbed behavior, which is underlain by abnormal mental and neural functions (Lewis \& Lieberman 2000). Patients with schizophrenia are often severely debilitated and lose contact with the real world. The characteristic symptoms of schizophrenia include two or more of the following, each present for a significant portion of a 1-month period: delusions; hallucinations; disorganized speech; grossly disorganized or catatonic behavior; and/or negative symptoms including flat or blunted emotions, avolition, limited speech, and general apathy (Lehman et al. 2004). Symptoms may be divided into three groups: mild and usually stable; moderate and often stable; and severe, unstable, and prone to relapse. Early diagnosis is important to reduce the risk of a full-blown episode already in a premorbid stage or the risk of an impending relapse, particularly as schizophrenia is believed to be a neurodevelopmental disorder in which clinical deterioration may start in the premorbid phase (Fig. 1). Patients with schizophrenia exhibit an increased prevalence of obesity, type 2 diabetes mellitus, and cardiovascular disease, when compared with the general population (Newcomer 2004). 


\section{Prevalence of schizophrenia}

Schizophrenia affects about $1 \%$ of the adult population worldwide (Clark 2005), but a further 2-3\% of the general population has a milder form of the disease, schizotypal personality disorder, and do not manifest overtly psychotic behavior (Kandel 2000; Lewis \& Lieberman 2000). The onset of schizophrenia usually occurs between adolescence and the age of 40 and may be divided into premorbid, prodromal, and psychotic phases; the psychotic phase may be subdivided into an early progressive phase and a later residual phase (Fig. 1). The age of overt schizophrenic symptoms closely parallel the reproductive period.

\section{Burden of illness}

According to Clark (2005), schizophrenia is associated with a disproportionately large share of the population's morbidity because it starts at an early age and is usually progressive, often with recurrent symptoms. Thus, in most developed countries $8 \%$ of hospital beds are occupied by patients with schizophrenia, many of whom may be homeless: the weighted average prevalence of schizophrenia among homeless people is 11\% (Folsom \& Jeste 2002). Approximately $50 \%$ of people with schizophrenia are found to have had problems with alcohol/substance abuse, and the disease is statistically associated with male gender and substance abuse (Folsom et al. 2005). Female patients tend to be older than males and are more likely to live independently (Lindamer et al. 2003). The suicide rate among people with schizophrenia is 20-50 times higher than that of the general population: $10 \%$ of people with schizophrenia commit suicide and $25 \%$ attempt it (Clark 2005). Furthermore, patients with schizophrenia often suffer from sexual dysfunction as a result either of the disease itself or as a side effect of the antipsychotic medications prescribed for them (Kelly \& Conley 2004).
From an economic standpoint, there are arguments for and against both inpatient and community care for patients. Although patients with schizophrenia in assisted living facilities make greater use of outpatient mental health services and have lower rates of psychiatric and medical hospitalization, their pharmacy costs and health costs are higher compared with those living independently or who are homeless (Gilmer et al. 2003). Lien (2005) suggests that community care is more effective than hospital-based care, except for the most disabled patients. In addition the families of patients with schizophrenia experience both financial and emotional burdens, the extent of which is related to the amount of symptomatic behavior of the patient (Lowyck et al. 2004).

\section{Pathophysiology of schizophrenia}

There is evidence to suggest that schizophrenia has a genetic basis and runs in families (Kandel 2000; Lewis \& Lieberman 2000). Regions on a number of chromosomes have been identified as sites of potential vulnerability. However, environmental factors are also thought to play a role in the pathogenesis of the disease, including exposure to infections, autoimmune responses, stress during gestation or childhood, and subtle disorders of brain development and maturation which do not become apparent until late adolescence and early adulthood (Fig. 1) (Lewis \& Lieberman 2000; Lieberman et al. 2001). Thus, schizophrenia is likely to be a polygenic disorder in which individuals are vulnerable to both developmental and environmental factors.

Recent studies suggest that specific areas of the genome may exhibit coinheritance with disease, e.g. specific areas of chromosome $5 p$ (Cooper-Casey et al. 2005), or that fragile $X$ syndrome is associated with very early onset schizophrenia (Vantalon et al. 2005). Owen et al. (2005) indicate that there are

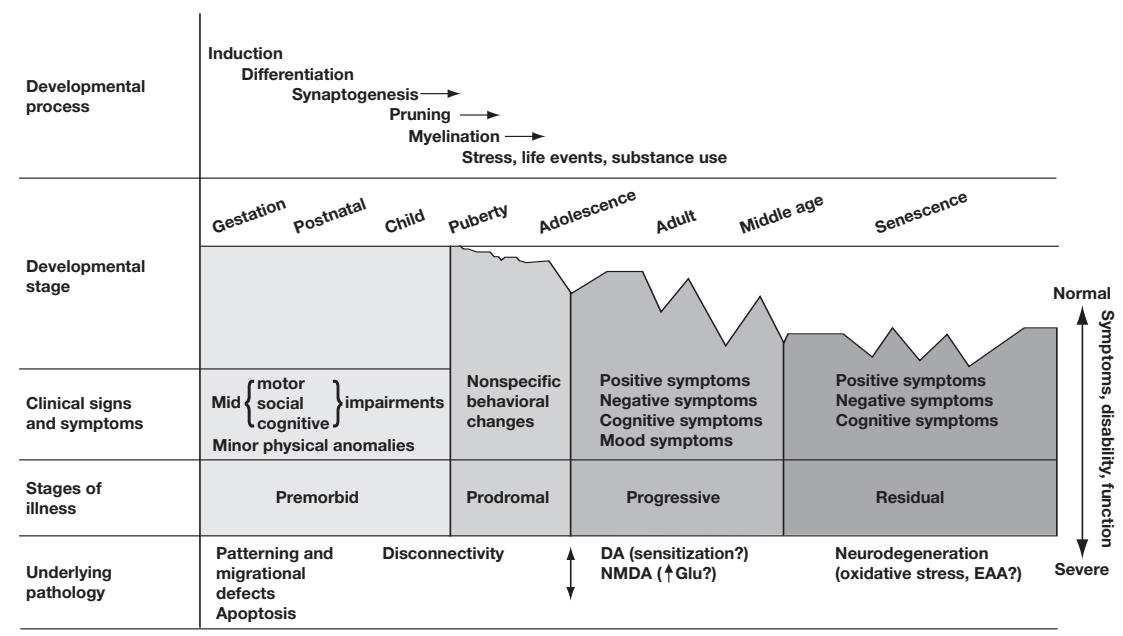

Fig. 1 | The pathophysiologic course of schizophrenia. Developmental process indicates neuronal maturational processes and environmental events that may unmask or destabilize vulnerable neural circuits. DA, dopamine; EAA, excitatory amino acids; Glu, glutamate; NMDA, N-methyl-D-aspartate. Adapted from Lieberman et al. 2001, Biol Psychiatry. 2001;50:884-897 with permission from the Society of Biological Psychiatry 
Table 2 | Summary of the pharmacology, advantages, and disadvantages of currently available atypical antipsychotics

\begin{tabular}{|c|c|c|c|c|}
\hline \multirow{2}{*}{$\begin{array}{l}\text { Atypical } \\
\text { antipsychotic }\end{array}$} & \multicolumn{2}{|c|}{ Receptor binding } & \multirow{2}{*}{$\begin{array}{l}\text { Other } \\
\text { pharmacologic } \\
\text { actions }\end{array}$} & \multirow[t]{2}{*}{ Advantages and disadvantages } \\
\hline & Agonist activity & Antagonist activity & & \\
\hline Amisulpride & & $D_{2}, D_{3}$ & $\begin{array}{l}\text { Acts preferentially on } \\
\text { presynaptic receptors } \\
\text { increasing dopaminergic } \\
\text { transmission at low } \\
\text { doses }\end{array}$ & $\begin{array}{l}\text { Advantages: quality of life is better than with haloperidol } \\
\text { Disadvantages: insomnia, anxiety, weight gain, dystonia, dose-related EPS, } \\
\text { tardive dyskinesia, hypotension, bradycardia and QT prolongation, } \\
\text { hyperprolactinemia }\end{array}$ \\
\hline Clozapine & $\mathrm{M}_{4}$ & $\begin{array}{l}\mathrm{D}_{1}-\mathrm{D}_{5}, 5 \mathrm{HT}_{1 \mathrm{~A}}, 5 \mathrm{HT}_{2 \mathrm{~A}} \\
5 \mathrm{HT}_{2 \mathrm{C}}, \mathrm{H}_{1}, \mathrm{M}_{1}, \mathrm{M}_{2} \\
\mathrm{M}_{4}, \mathrm{M}_{5}, \alpha_{1} \text { and } \alpha_{2} \\
\text { adrenergic }\end{array}$ & NR & $\begin{array}{l}\text { Advantages: effective in treatment-resistant schizophrenia, no signs of EPS } \\
\text { Disadvantages: sedation, weight gain, high risk of new onset diabetes }\end{array}$ \\
\hline Risperidone & & $\begin{array}{l}\mathrm{D}_{1}-\mathrm{D}_{4}, 5 \mathrm{HT}_{1 \mathrm{~A}}, 5 \mathrm{HT}_{2 \mathrm{~A}} \\
5 \mathrm{HT}_{2 \mathrm{C}}, \mathrm{H}_{1}, \alpha_{1} \text { and } \alpha_{2} \\
\text { adrenergic }\end{array}$ & NR & $\begin{array}{l}\text { Advantages: less potential for causing EPS than haloperidol } \\
\text { Disadvantages: insomnia, anxiety, headache, somnolence, dizziness, poor } \\
\text { concentration, sexual dysfunction, weight gain }\end{array}$ \\
\hline Olanzapine & & $\begin{array}{l}\mathrm{D}_{1}-\mathrm{D}_{4}, 5 \mathrm{HT}_{2 \mathrm{~A}}, 5 \mathrm{HT}_{2 \mathrm{C}} \\
\mathrm{H}_{1}, \mathrm{M}_{1}, \mathrm{M}_{2}, \mathrm{M}_{4}, \mathrm{M}_{5} \\
\alpha_{1} \text { adrenergic }\end{array}$ & NR & $\begin{array}{l}\text { Advantages: no signs of EPS at lower doses } \\
\text { Disadvantages: sedation, weight gain, high risk of new onset diabetes }\end{array}$ \\
\hline Quetiapine & & $\begin{array}{l}\mathrm{D}_{1}, \mathrm{D}_{2}, 5 \mathrm{HT}_{1 \mathrm{~B} / 1 \mathrm{D}} \\
5 \mathrm{HT}_{2 \mathrm{~A}}, 5 \mathrm{HT}_{2 \mathrm{C}}, \mathrm{H}_{1} \\
\alpha_{1} \text { adrenergic }\end{array}$ & NR & $\begin{array}{l}\text { Advantages: no signs of EPS } \\
\text { Disadvantages: moderate sedation, some weight gain, risk of new } \\
\text { onset diabetes }\end{array}$ \\
\hline Ziprasidone & $5 \mathrm{HT}_{1 \mathrm{~A}}{ }^{\mathrm{a}}$ & $\begin{array}{l}\mathrm{D}_{2}, 5 \mathrm{HT}_{1 \mathrm{~A}}, 5 \mathrm{HT}_{2 \mathrm{~A}} \\
5 \mathrm{HT}_{2 \mathrm{C}}, \mathrm{H}_{1}, \alpha_{1} \\
\text { adrenergic }\end{array}$ & $\begin{array}{l}\text { Inhibits neuronal } \\
\text { reuptake of serotonin } \\
\text { and norepinephrine }\end{array}$ & $\begin{array}{l}\text { Advantages: well tolerated } \\
\text { Disadvantages: somnolence, nausea, constipation, dyspepsia, akathisia, } \\
\text { dizziness, diarrhea, QTc prolongation }\end{array}$ \\
\hline
\end{tabular}

associations between DNA polymorphisms and schizophrenia and that the genes most clearly implicated all code for proteins with a potential impact on the function of glutamate synapses. These synapses could be the site of primary abnormalities that disrupt downstream neural circuits; however, this remains to be demonstrated. In addition, patients with Klinefelter's syndrome, which is characterized by an additional $\mathrm{X}$ chromosome, are likely to have structural abnormalities of the amygdala and are at an increased risk of schizophrenia (van Rijn et al. 2005). Other neural structures altered in patients with schizophrenia include the hippocampus, prefrontal cortex, and dorsal thalamus (Owen et al. 2005).

According to Lieberman et al. (2001), the formal onset of schizophrenia is preceded by significant neurodevelopmental abnormalities starting in early childhood. Several neurotransmitter systems appear to be involved including dopaminergic, serotonergic, gamma-aminobutyric acid (GABA)-ergic, and glutamatergic neurons (Table 2) (Lieberman 2004). Typical and atypical antipsychotics are dopamine $\left(D_{2}\right)$ receptor antagonists to some extent. However, atypical antipsychotics bind with other receptor types, particularly serotonin $\left(5 \mathrm{HT}_{2 \mathrm{~A}}\right)$ receptors, which may account for the differences in clinical activity compared with conventional antipsychotics. Antagonism of $D_{2}$ receptors has been suggested to account for the effectiveness of both groups of antipsychotics against the positive symptoms of schizophrenia, while antagonism of $5 \mathrm{HT}_{2 \mathrm{~A}}$ receptors appears to have beneficial effects on its negative symptoms by indirectly increasing dopamine synthesis in the prefrontal cortex because $5 \mathrm{HT}_{2 \mathrm{~A}}$ receptor antagonism inhibits serotonin release in the nigrostriatal and mesolimbic pathways, leading to increased dopaminergic transmission (Lieberman et al. 1998; Lieberman 2004). Since atypical antipsychotics interact with several other types of receptors (Table 2), several other systems of neurons could also be modulated by them.

Aripiprazole and bifeprunox are atypical antipsychotics that act as partial agonists at $D_{2}$ receptors, although only aripiprazole is available clinically at present. These agents act as functional antagonists of dopamine in areas of the brain where excessive dopamine activity is believed to cause positive symptoms of schizophrenia, such as the mesolimbic dopamine pathway, while acting as partial agonists in the mesocortical pathway where negative symptoms and cognitive impairment are thought to be associated with reduced levels of dopamine (Lieberman 2004). Furthermore, $D_{2}$ partial agonists may avoid blockade of $D_{2}$ receptors in the nigrostriatal pathway, which could cause extrapyramidal symptoms (EPS), as well as in the tuberoinfundibular pathway, which could lead to elevated prolactin levels.

\section{Current therapy options}

The main outcomes of antipsychotic therapy should include stabilization of acute psychotic symptoms, early rehabilitation, reduction of the likelihood of relapse, decreased alcohol/substance abuse, improved quality of life, and reduced family disruption. 
The primary treatments for schizophrenia are conventional antipsychotic drugs, often referred to as first-generation antipsychotics, and atypical antipsychotics, also known as second-generation antipsychotics. Although conventional antipsychotics have been demonstrated to be efficacious to varying degrees, they have been associated with increased rates of EPS (including acute dystonias and tardive dyskinesia), increased prolactin secretion (which may be associated with sexual dysfunction), sedation, hypotension, weight gain, dry mouth, and blurred vision (Lehman et al. 2004). In general, atypical antipsychotics are now recommended as the treatment of choice for patients with schizophrenia because, in comparison to conventional antipsychotics, they have been associated with a lower incidence of EPS (Lehman et al. 2004). They have also been shown to be more efficacious than conventional antipsychotics in treating the negative symptoms and cognitive dysfunction associated with schizophrenia.

Internationally, clinical guidelines agree that atypical antipsychotics should be considered as first-line medication for patients in the acute phase of schizophrenia because there is a decreased risk of EPS and tardive dyskinesia (NICE 2002a; Lehman et al. 2004; Falkai et al. 2005; RANZCP 2005). They also state that at present there is no definitive evidence that one atypical antipsychotic is better than another.
Despite the guideline recommendations, currently available atypical antipsychotic drugs are not without their drawbacks. Metabolic disturbance including hyperlipidemia, diabetes, and excessive weight gain are associated with some of these drugs in vulnerable individuals (Mortimer 2003; Newcomer 2004), which may increase the risk of cardiovascular disease in patients treated with atypical antipsychotics compared with conventional antipsychotics (Mortimer 2003; Liberty et al. 2004; Lublin et al. 2005). In addition, all of the currently available atypical antipsychotics have been associated with sedation (Lublin et al. 2005), and some may cause sexual difficulties in both males and females (Kelly \& Conley 2004).

A gap therefore clearly remains between what might be considered an "ideal" antipsychotic agent and the currently available options. From a clinical perspective, the ideal agent would be one that rapidly stabilizes acute psychotic symptoms, both positive and negative, and maintains the patient without relapse for prolonged periods in the absence of extrapyramidal, endocrine, diabetic, or cardiovascular side effects, without weight gain or sedation. It should also be effective in patients with treatment resistance symptoms, in whom the only currently available option is clozapine, which is poorly tolerated (Mortimer, personal communication).

Table 3 | Level 2 evidence of the effects of aripiprazole on schizophrenia and schizoaffective disorder outcomes: PANSS and CGI scores

\begin{tabular}{|c|c|c|c|c|c|c|c|}
\hline \multirow[t]{2}{*}{ Reference } & \multirow[t]{2}{*}{ Design } & \multirow{2}{*}{$\begin{array}{l}\text { Treatment } \\
\text { (no. patients) }\end{array}$} & \multicolumn{5}{|c|}{ Outcome $^{a}$} \\
\hline & & & PANSS & PANSS-P & PANSS-N & CGI-I & CGI-S \\
\hline \multirow[t]{4}{*}{ Kane et al. 2002} & \multirow{4}{*}{$\begin{array}{l}4 \mathrm{w}, \mathrm{db} \\
\mathrm{mc}\end{array}$} & Ari 15 mg/d (102) & $-15.5(P<0.001)$ & $-4.2(P<0.001)$ & $-3.6(P=0.006)$ & $+3.5(P<0.001)$ & -0.6 \\
\hline & & Ari 30 mg/d (102) & $-11.4(P=0.009)$ & $-3.8(P=0.001)$ & -2.3 (NS) & $+3.8(P=0.016)$ & -0.4 \\
\hline & & Hal 10 mg/d (104) & $-13.8(P=0.001)$ & $-4.4(P<0.001)$ & $-2.9(P=0.043)$ & $+3.7(P=0.002)$ & -0.5 \\
\hline & & Placebo (106) & -2.9 & -0.6 & -1.2 & +4.3 & -0.1 \\
\hline \multirow[t]{3}{*}{ Casey et al. 2003} & \multirow[t]{3}{*}{$\begin{array}{l}8 \mathrm{w}, \\
\text { open, mc }\end{array}$} & $\begin{array}{l}\text { Ari } 30 \mathrm{mg} / \mathrm{d} \\
\text { immed disc other } \\
\mathrm{Rx}(103)\end{array}$ & -7.59 & -1.59 & -2.88 & +3.17 & -0.43 \\
\hline & & $\begin{array}{l}\text { Ari } 30 \text { mg/d taper } \\
\text { off other Rx (104) }\end{array}$ & -8.18 & -2.00 & -2.37 & +3.31 & -0.37 \\
\hline & & $\begin{array}{l}\text { Ari } 10-30 \mathrm{mg} / \mathrm{d} \\
\text { titrate, taper off } \\
\text { other } \mathrm{Rx}(102)\end{array}$ & -10.11 & -2.75 & -2.81 & +3.16 & -0.39 \\
\hline \multirow[t]{2}{*}{ Pigott et al. 2003} & \multirow{2}{*}{$\begin{array}{l}26 \mathrm{w}, \mathrm{db} \\
\mathrm{mc}\end{array}$} & Ari 15 mg/d (148) & $-2.08(P \leq 0.01)$ & $+0.12(P \leq 0.01)$ & -1.4 & $+3.74(P \leq 0.01)$ & $+0.15(P \leq 0.05)$ \\
\hline & & Placebo (149) & +4.5 & +2.37 & -0.54 & +4.47 & +0.4 \\
\hline \multirow[t]{4}{*}{ Potkin et al. 2003} & \multirow{4}{*}{$\begin{array}{l}4 \mathrm{w}, \mathrm{db} \\
\mathrm{mc}\end{array}$} & Ari 20 mg/d (98) & $-14.5(P=0.001)$ & $-4.9(P=0.001)$ & $-3.4(P=0.002)$ & $+3.4(P=0.005)$ & $-0.5(P=0.03)$ \\
\hline & & Ari 30 mg/d (96) & $-13.9(P=0.003)$ & $-3.9(P=0.02)$ & $-3.4(P=0.002)$ & $+3.3(P=0.001)$ & $-0.6(P=0.006)$ \\
\hline & & Ris 6 mg/d (95) & $-15.7(P<0.001)$ & $-5.2(P<0.001)$ & $-3.1(P=0.005)$ & $+3.3(P<0.001)$ & $-0.7(P<0.001)$ \\
\hline & & Placebo (103) & -5.0 & -1.8 & -0.8 & +4.0 & -0.2 \\
\hline \multirow[t]{3}{*}{ Tandon et al. 2006} & \multirow{3}{*}{$\begin{array}{l}8 \mathrm{w}, \\
\text { open, mc }\end{array}$} & Ari 10-30 (mean & $N R$ & NR & NR & +2.77 & NR \\
\hline & & 19.9) mg/d (1255) & NR & NR & NR & +3.59 & NR \\
\hline & & Control $^{b}(265)$ & & & & & \\
\hline \multicolumn{8}{|c|}{$\begin{array}{l}\text { aSignificance levels all vs placebo; all results from last-observation-carried-forward (LOCF) analysis. } \\
\text { 'Ziprasidone (38\%), risperidone (20\%), quetiapine (19\%), olanzapine (12\%), clozapine (1\%), unspecified typical antipsychotic (7\%), unspecified other antipsychotic(s) (3\%). } \\
\text { Ari, aripiprazole; CGI-I, Clinical Global Impression-Global Improvement Scale; CGI-S, Clinical Global Impressions-Severity of Illness Scale; d, day; db, double-blind; disc, discontinuation } \\
\text { Hal, haloperidol; immed, immediate; mc, multicenter; NR, not reported; PANSS, Positive And Negative Syndrome Scale; PANSS-N, Positive And Negative Syndrome Scale-negative } \\
\text { symptoms; PANSS-P, Positive And Negative Syndrome Scale-positive symptoms; Ris, risperidone; Rx, treatment; w, week. }\end{array}$} \\
\hline
\end{tabular}


Table 4 | Level 2 evidence of response rates to aripiprazole in patients with schizophrenia or schizoaffective disorder

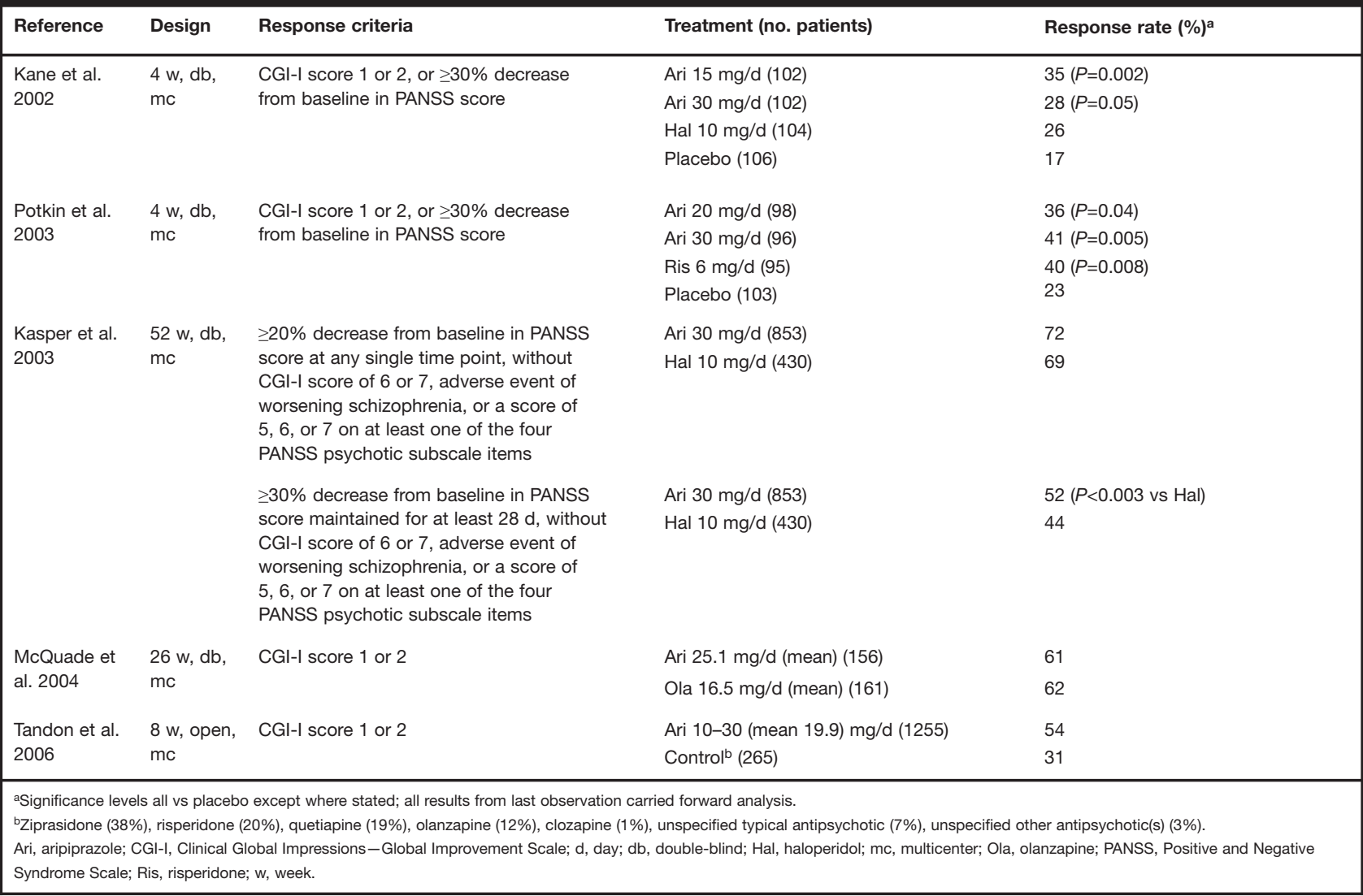

Aripiprazole is a partial $D_{2}$ agonist (Launer 2005; Ohlsen \& Pilowsky 2005), but in addition it appears to stabilize dopamine and serotonin levels (Burris et al. 2002). It is pharmacologically distinct from the other atypical antipsychotics with partial agonist activity at both $\mathrm{D}_{2}$ and $5 \mathrm{HT}_{1 \mathrm{~A}}$ receptors, and a high affinity for $\mathrm{D}_{3}, 5 \mathrm{HT}_{2 \mathrm{~A}}$, and $5 \mathrm{HT}_{2 \mathrm{~B}}$ receptors (Burris et al. 2002; Jordan et al. 2002; Shapiro et al. 2003). It also has moderate affinity for $\mathrm{D}_{4}, 5 \mathrm{HT}_{2 \mathrm{C}}, 5 \mathrm{HT}_{7}$, and alfa ${ }_{1}$-adrenergic and histamine $\left(\mathrm{H}_{1}\right)$ receptors (Shapiro et al. 2003). Aripiprazole is indicated for the treatment of schizophrenia and acute manic and mixed episodes associated with bipolar disorder.

\section{Clinical evidence for aripiprazole in schizophrenia}

The literature search revealed nine complete randomized controlled trials (RCTs) on aripiprazole. Attrition rates were high (34-72\%) as previously noted by El-Sayeh and Morganti (2004). In both long- and short-term studies serious adverse events were mostly related to the underlying diagnosis, particularly worsening of psychosis (Marder et al. 2003), to which many of the discontinuations have been attributed. This level of discontinuation in trials in patients with schizophrenia does not appear to be particularly unusual (Mortimer, personal communication), and has been attributed to placebocontrolled study design (Kemmler et al. 2005). A number of abstracts of recent studies are also available; those with sufficient detail have been included in the analysis, but none appeared to be RCTs.

\section{Reduction of symptoms of schizophrenia/schizoaffective disorder}

Reduction in symptoms was the primary endpoint in RCTs of aripiprazole in patients with schizophrenia, using a number of scales. The Positive And Negative Syndrome Scale (PANSS) consists of 30 items on a 7-point scale, and can be used to assess general psychologic status, and positive and negative symptoms. A higher score indicates greater severity. The Clinical Global Impressions-Severity of Illness Scale (CGI-S), and CGI-Global Improvement Scale (CGI-I) assess severity of illness and clinical improvement, with higher scores on a 7-point scale again indicating worsening of illness.

There is strong evidence that aripiprazole was effective in reducing the symptoms of schizophrenia and schizoaffective disorder at daily doses of 15-30 mg/day (Table 3). Both positive and negative symptoms were reduced, and aripiprazole was at least as effective as risperidone and haloperidol. Significantly greater efficacy $(P<0.05)$ for aripiprazole against negative symptoms compared with haloperidol was reported in one study involving 495 patients (Kasper et al. 2003). Onset of action of aripiprazole was rapid, with 
Table 5 | Level 1 evidence (meta analysis within a systematic review) of aripiprazole discontinuation in patients with schizophrenia or schizoaffective disorder (El-Sayeh \& Morganti 2004)

Treatment (no. patients)

Number of patients leaving study early (\%)

\begin{tabular}{|c|c|c|}
\hline & \\
\hline & Any reason & Adverse effects \\
\hline \multicolumn{3}{|l|}{ Aripiprazole vs placebo (6 RCTs) } \\
\hline Aripiprazole $(\mathrm{n}=1087)$ & $477(44 \%)$ & $66(6 \%)$ \\
\hline Placebo $(n=571)$ & $345(60 \%)$ & $43(8 \%)$ \\
\hline Relative risk [confidence interval] & $0.68[0.55,0.86]$ & $0.82[0.40,1.70]$ \\
\hline \multicolumn{3}{|c|}{ Aripiprazole vs typical antipsychotics (5 RCTs) } \\
\hline Aripiprazole $(n=1433)$ & $691(48 \%)$ & $118(8 \%)$ \\
\hline Typical antipsychotics $(\mathrm{n}=780)$ & $419(54 \%)$ & $110(14 \%)$ \\
\hline Relative risk [confidence interval] & $0.90[0.76,1.05]$ & $0.77[0.37,1.60]$ \\
\hline \multicolumn{3}{|c|}{ Aripiprazole vs atypical antipsychotics (2 RCTs) } \\
\hline Aripiprazole $(n=358)$ & $191(53 \%)$ & $18(5 \%)$ \\
\hline Atypical antipsychotics $(n=260)$ & $150(58 \%)$ & $21(8 \%)$ \\
\hline Relative risk [confidence interval] & $1.05[0.93,1.19]$ & $0.78[0.42,1.42]$ \\
\hline
\end{tabular}

symptom scores decreasing significantly within 2 weeks of initiating treatment, and was maintained for up to 52 weeks (Kasper et al. 2003). A post-hoc pooled analysis of five short-term studies (4 to 6 weeks) demonstrated that aripiprazole was significantly more effective than placebo and comparable to haloperidol in alleviating hostility in patients with schizophrenia or schizoaffective disorder (Volavka et al. 2005).

The evidence for the efficacy of aripiprazole is strong both in patients experiencing an acute relapse (Kane et al. 2002; Kasper et al. 2003; Potkin et al. 2003), and in patients with chronic stable disease (Casey et al. 2003; Pigott et al. 2003), in whom consistent and progressive symptom improvement has been reported for up to 8 weeks (Casey et al. 2003).

\section{Reduction in mood symptoms associated with schizophrenia}

Mood symptoms, particularly schizophrenia-associated depression and anxiety, are an important consideration in the management of patients with schizophrenia. The effect of aripiprazole on these symptoms has been assessed as a secondary endpoint. There is evidence that aripiprazole is significantly more effective than placebo $(P=0.001)$ (Carson et al. 2003) and haloperidol $(P<0.05)$ (Carson et al. 2003; Kasper et al. 2003) in improving depressive symptoms as assessed by factor analysis of PANSS scores or by the Montgomery-Asberg Depression Rating Scale. The effect of aripiprazole was significant at 4 to 6 weeks (Carson et al. 2003), and was maintained for up to 52 weeks (Kasper et al. 2003).

\section{Prevention of relapse in stabilized patients}

There is evidence from one randomized, double-blind, multicenter trial that aripiprazole is less frequently associated with relapse compared with placebo in patients with chronic stable schizophrenia [Diagnostic and Statistical Manual of Mental Disorders-Fourth Edition (DSM-IV) criteria] (Pigott et al. 2003). In 297 evaluable patients, time to relapse was significantly longer $(P<0.001)$ in the group receiving aripiprazole $15 \mathrm{mg} /$ day compared with placebo, and fewer patients relapsed (34 vs $57 \%$ ) after 26 weeks. As a measure of efficacy, the relative risk (RR) of relapse for aripiprazole compared with placebo was calculated as 0.59 [95\% confidence interval $(\mathrm{Cl}) 0.45,0.75 ; P<0.001]$. This study used relapse criteria which were more stringent than those defined in previous studies with atypical antipsychotic therapy, and represent a deterioration rather than a specific event (El-Sayeh \& Morganti 2004).

\section{Response rate}

An alternative to clozapine to overcome treatment resistance is a major unmet need in the management of patients with schizophrenia. Five studies provide evidence of the response rate to aripiprazole, using various combinations of symptom score reductions (Table 4). All patients in these studies were experiencing acute relapse of schizophrenia, and had previously responded to antipsychotic medication other than clozapine (i.e. they were not treatment resistant).

Response to aripiprazole 15-30 mg/day was significantly greater than for placebo, and comparable to risperidone $6 \mathrm{mg} / \mathrm{day}$ (Potkin et al. 2003) and haloperidol $10 \mathrm{mg} /$ day after 4 weeks (Kane et al. 2002). However, in the longer term more patients appear to respond to aripiprazole than to haloperidol. After 52 weeks, response rates (defined as $\geq 30 \%$ decrease from baseline in PANSS score maintained for at least 28 days, without CGI-I score of 6 or 7 , adverse event of worsening schizophrenia, or a score of 5,6 , or 7 on at least one of the four PANSS psychotic subscale items) to aripiprazole compared with haloperidol were 52 vs $44 \% \quad(P<0.003)$, and proportion of patients failing to 
maintain a response at week 52 was 85 vs $79 \%$ (RR 0.70; 95\% Cl $0.45,1.07$; $P=0.098$ ) (Kasper et al. 2003).

\section{Reduced discontinuation rates}

There is a solid body of evidence that fewer patients taking aripiprazole discontinue treatment. This evidence comprises a meta analysis of RCTs (level 1 evidence), as well as level 3 evidence from a large database of patients with schizophrenia or schizoaffective disorder.

The level 1 evidence indicates that significantly fewer patients taking aripiprazole left the study early compared with those taking placebo, typical antipsychotics, or atypical antipsychotics (Table 5). Nevertheless, approximately half of all aripiprazole recipients did not complete the full course of study treatment, calling the results into question. Similar discontinuation rates in trials in patients with schizophrenia are not uncommon (Mortimer, personal communication). Adverse events do not appear to be the cause of this attrition rate (El-Sayeh \& Morganti 2004).

Table 6 shows the reasons reported for treatment discontinuation in RCTs of aripiprazole in patients with schizophrenia and schizoaffective disorder. Worsening of illness and insufficient clinical response was often just as, or more, likely to be the cause of discontinuing aripiprazole as adverse events. With the exception of the study by Pigott et al. (2003), other reasons were the commonest cause of stopping treatment, usually related to violation of or noncompliance with study design, and applying to all study groups.

Level 3 evidence from a database of 2947 patients with schizophrenia or schizoaffective disorder demonstrated that aripiprazole-treated patients exhibited the lowest risk for discontinuation [hazard ratio (HR) $0.60 ; 95 \% \mathrm{Cl} 0.50,0.72$ ] compared with conventional antipsychotics and the atypical antipsychotics quetiapine (HR 0.67; 95\% Cl 0.56, 0.80), ziprasidone (HR 0.74; 95\% Cl 0.60, 0.91), risperidone (HR 0.79; $95 \% \mathrm{Cl} 0.67,0.95)$, and olanzapine (HR 0.83; 95\% Cl 0.70, 0.99) (Olfson et al. 2005b).

Likewise, the risk of rehospitalization in a database of 576 patients was significantly lower for aripiprazole (HR $0.27 ; 95 \% \mathrm{Cl}$ $0.08,0.91$ ) and olanzapine (HR $0.41 ; 95 \% \mathrm{Cl} 0.20,0.84$ ) compared with typical antipsychotics (Carrigan et al. 2005), but was not significantly lower for risperidone (HR 0.53; 95\% Cl 0.27 ,

Table 6 | Causes of treatment discontinuation in RCTs of aripiprazole in patients with schizophrenia and schizoaffective disorder

\begin{tabular}{|c|c|c|c|c|c|c|c|}
\hline \multirow[t]{2}{*}{ Reference } & \multirow[t]{2}{*}{ Design } & \multirow{2}{*}{$\begin{array}{l}\text { Treatment } \\
\text { (no. patients) }\end{array}$} & \multicolumn{4}{|c|}{ Reason for discontinuation, proportion of patients (\%) } & \multirow{2}{*}{$\begin{array}{c}\text { Total patients } \\
\text { discontinued }(\%)^{\mathrm{a}}\end{array}$} \\
\hline & & & $\begin{array}{l}\text { Insufficient clinical } \\
\text { response/lack of } \\
\text { efficacy (relapse) }\end{array}$ & $\begin{array}{c}\text { Worsening } \\
\text { schizophrenia }^{b}\end{array}$ & Adverse events & Otherc & \\
\hline \multirow{4}{*}{$\begin{array}{l}\text { Kane et al. } \\
2002\end{array}$} & \multirow[t]{4}{*}{$4 \mathrm{w}, \mathrm{db}, \mathrm{mc}$} & Ari 15 mg/d (102) & 5 & NR & 9 & 20 & 33 \\
\hline & & Ari 30 mg/d (102) & 15 & NR & 8 & 19 & 41 \\
\hline & & Hal 10 mg/d (104) & 6 & NR & 11 & 24 & 40 \\
\hline & & Placebo (106) & 14 & NR & 16 & 15 & 45 \\
\hline \multirow[t]{3}{*}{$\begin{array}{l}\text { Casey et al. } \\
2003\end{array}$} & \multirow[t]{3}{*}{8 w, open, mc } & $\begin{array}{l}\text { Ari } 30 \mathrm{mg} / \mathrm{d} \text { immed } \\
\text { disc other } \mathrm{Rx}(104)\end{array}$ & NR & 10 & 6 & 15 & 31 \\
\hline & & $\begin{array}{l}\text { Ari } 30 \mathrm{mg} / \mathrm{d} \text { taper } \\
\text { off other Rx (104) }\end{array}$ & NR & 10 & 10 & 14 & 34 \\
\hline & & $\begin{array}{l}\text { Ari } 10-30 \mathrm{mg} / \mathrm{d} \\
\text { titrate, taper off } \\
\text { other } \mathrm{Rx}(103)\end{array}$ & NR & 8 & 6 & 6 & 19 \\
\hline \multirow{2}{*}{$\begin{array}{l}\text { Kasper et al. } \\
2003\end{array}$} & \multirow[t]{2}{*}{$52 \mathrm{w}, \mathrm{db}, \mathrm{mc}$} & Ari 30 mg/d (861) & 7 & 17 & 8 & 25 & 57 \\
\hline & & Hal 10 mg/d (433) & 9 & 13 & 19 & 30 & 70 \\
\hline \multirow{2}{*}{$\begin{array}{l}\text { Pigott et al. } \\
2003\end{array}$} & \multirow[t]{2}{*}{$26 \mathrm{w}, \mathrm{db}, \mathrm{mc}$} & Ari 15 mg/d (155) & $27^{d}$ & NR & 10 & $17^{e}$ & 54 \\
\hline & & Placebo (155) & $49^{d}$ & NR & 8 & 14 & 71 \\
\hline \multirow{4}{*}{$\begin{array}{l}\text { Potkin et al. } \\
2003\end{array}$} & \multirow[t]{4}{*}{$4 \mathrm{w}, \mathrm{db}, \mathrm{mc}$} & Ari 20 mg/d (101) & 9 & NR & 11 & 20 & 40 \\
\hline & & Ari 30 mg/d (101) & 8 & NR & 8 & 18 & 34 \\
\hline & & Ris 6 mg/d (99) & $\begin{array}{c}8 \\
17\end{array}$ & $\begin{array}{l}\text { NR } \\
\text { NR }\end{array}$ & 8 & 21 & 37 \\
\hline & & Placebo (103) & & & 17 & 17 & 50 \\
\hline \multirow[t]{2}{*}{$\begin{array}{l}\text { Tandon et al. } \\
2006\end{array}$} & \multirow[t]{2}{*}{8 w, open, mc } & $\begin{array}{l}\text { Ari 10-30 (mean } \\
\text { 19.9) } \mathrm{mg} / \mathrm{d}(1255)\end{array}$ & 3.8 & NR & 17 & 5.9 & 35 \\
\hline & & Control $^{f}(265)$ & 7.6 & NR & 11.5 & 13.2 & 43 \\
\hline \multicolumn{8}{|c|}{$\begin{array}{l}\text { aIndividual numbers in each column may not add up to total due to rounding. } \\
\text { bDefined by the modified COSTART dictionary terms "psychosis" and "schizophrenic reaction"; the majority of these events represent a relapse of the primary disease and are not considered } \\
\text { attributable to study medication (Kasper et al. 2003). Not defined for Casey et al. } 2003 \text {. } \\
\text { "Other known causes included lost to follow-up, patient withdrew consent, patient met withdrawal criteria, study participation terminated by sponsor, protocol violation, laboratory } \\
\text { abnormalities, positive cannabinoid screening, anemia, randomization error, and noncompliance. } \\
\text { dLack of efficacy (relapse) stated as a reason for discontinuation. } \\
\text { eIncludes one death. } \\
\text { 'Ziprasidone ( } 38 \%) \text {, risperidone (20\%), quetiapine (19\%), olanzapine (12\%), clozapine (1\%), unspecified typical antipsychotic }(7 \%) \text {, unspecified other antipsychotic(s) (3\%). } \\
\text { Ari, aripiprazole; COSTART, Coding Symbols for Thesaurus of Adverse Reaction Terms; d, day; db, double-blind; disc, discontinuation; Hal, haloperidol; immed, immediate; mc, multicenter; } \\
\text { NR, not reported; RCT, randomized controlled trial; Ris, risperidone; Rx, treatment; w, week. }\end{array}$} \\
\hline
\end{tabular}


1.05), quetiapine ( $\mathrm{HR} 0.63 ; 95 \% \mathrm{Cl} 0.31,1.27)$, and ziprasidone (HR 0.76; 95\% Cl 0.37, 1.58).

\section{Safety and tolerability of aripiprazole}

Table 7 shows the level 1 evidence of the adverse effects encountered during trials with aripiprazole in patients with schizophrenia and schizoaffective disorder (El-Sayeh \& Morganti 2004).

The incidence of anxiety, headache, insomnia, and nausea was similar in patients receiving aripiprazole or placebo (Table 7). Compared with the typical antipsychotic perphenazine, aripiprazole was associated with a greater frequency of insomnia and dyspepsia, although this was not significant (El-Sayeh \& Morganti 2004). Similarly, in a 4-week study, nausea was more frequent in patients taking aripiprazole 15 or $30 \mathrm{mg} /$ day (15 and 14\%, respectively) compared with those receiving haloperidol $10 \mathrm{mg} /$ day $(6 \%)$, as was dizziness (13 and 17 vs $6 \%$ ) (Kane et al. 2002). Nausea was mild and transient in nature, resolving within 1 week. The incidence of insomnia was similar in all patients (19 and 22 vs $24 \%$ ), but somnolence was more common in those taking haloperidol (5 and 10 vs 13\%). In a longer-term study, the incidence of headache, anxiety, insomnia, and somnolence did not differ between aripiprazole or haloperidol after 52 weeks' treatment (Kasper et al. 2003).

Compared with the atypical antipsychotics risperidone and olanzapine, aripiprazole was associated with a greater frequency of anxiety, headache, insomnia, and nausea, but not significantly (Table 7).

There is level 2 evidence of a similar safety and tolerability profile for aripiprazole in real-world practice settings. Adverse events reported by $\geq 5 \%$ of 1255 aripiprazole recipients in a multicenter, prospective, open-label study included insomnia (24\%), nausea $(16 \%)$, headache $(11 \%)$, anxiety $(10 \%)$, somnolence $(8 \%)$, agitation (7\%), lightheadedness (6\%), diarrhea (6\%), vomiting $(5 \%)$, and psychosis (5\%) (Tandon et al. 2006).

\section{Extrapyramidal symptoms}

Level 1 evidence from RCTs indicates that there was no significant difference in the occurrence of EPS, including akathisia and need for antiparkinsonian medication, in patients treated with aripiprazole or placebo (15 vs $8 \%$ ) (El-Sayeh \& Morganti 2004). There is also level 1 evidence that the need for antiparkinsonian treatment was significantly reduced in aripiprazole recipients compared with those taking a typical antipsychotic (22 vs $51 \%$; RR 0.45; 95\% Cl 0.33, 0.6) (El-Sayeh \& Morganti 2004), although the incidence of akathisia and general EPS was not significantly different. This may be because that there were too few studies and hence too little power to detect a difference (El-Sayeh \& Morganti 2004).

Indeed, level 2 evidence does indicate a lower frequency of EPS in aripiprazole recipients compared with the typical antipsychotic haloperidol (Table 8). The evidence also suggests a similar rate of EPS with aripiprazole compared with the atypical antipsychotics risperidone and olanzapine (Potkin et al. 2003; El-Sayeh \& Morganti 2004; McQuade et al. 2004). In studies on patients following acute relapse, symptoms of EPS were observed with similar frequency in patients treated with aripiprazole 15-30 mg/day (17\%) and olanzapine 10-20 mg/day (16\%) (McQuade et al. 2004) after 26 weeks, and after 52 weeks aripiprazole $30 \mathrm{mg} /$ day was associated with significantly lower EPS assessments (10\%) than haloperidol $10 \mathrm{mg} /$ day (30\%; $P<0.001$ ) (Kasper et al. 2003).

Table 7 | Level 1 evidence (meta analysis within a systematic review) of incidence of adverse effects with aripiprazole in patients with schizophrenia or schizoaffective disorder (El-Sayeh \& Morganti 2004)

Treatment (no. patients)

Number of patients with adverse effects $(\%)$

\begin{tabular}{|c|c|c|c|c|}
\hline & \\
\hline & Anxiety & Headache & Insomnia & Nausea/dyspepsia \\
\hline \multicolumn{5}{|l|}{ Aripiprazole vs placebo (2 RCTs) } \\
\hline Aripiprazole $(n=357)$ & $64(18 \%)$ & $80(22 \%)$ & $120(34 \%)$ & $27(7 \%)$ \\
\hline Placebo $(n=258)$ & $53(20 \%)$ & $49(19 \%)$ & $86(33 \%)$ & $17(6 \%)$ \\
\hline Relative risk $[\mathrm{Cl}]$ & $0.86[0.53,1.39]$ & $1.04[0.76,1.43]$ & $1.09[0.87,1.37]$ & $1.05[0.59,1.88]$ \\
\hline \multicolumn{5}{|l|}{$\begin{array}{l}\text { Aripiprazole vs typical } \\
\text { antipsychotics (1 RCT) }\end{array}$} \\
\hline Aripiprazole $(n=154)$ & $17(11 \%)$ & $9(6 \%)$ & $73(47 \%)$ & $17(11 \%)$ \\
\hline Typical antipsychotics ${ }^{a}(n=146)$ & $19(13 \%)$ & $13(9 \%)$ & $31(21 \%)$ & $9(6 \%)$ \\
\hline Relative risk $[\mathrm{Cl}]$ & $0.85[0.46,1.57]$ & $0.66[0.29,1.49]$ & $2.23[1.57,3.18]$ & $1.79[0.82,3.89]$ \\
\hline \multicolumn{5}{|l|}{$\begin{array}{l}\text { Aripiprazole vs atypical } \\
\text { antipsychotics ( } 2 \text { RCTs) }\end{array}$} \\
\hline Aripiprazole $(n=330)$ & $64(19 \%)$ & $86(26 \%)$ & $95(29 \%)$ & $41(12 \%)$ \\
\hline Atypical antipsychotics $(n=226)$ & $23(10 \%)$ & $48(21 \%)$ & $34(15 \%)$ & $20(9 \%)$ \\
\hline Relative risk $[\mathrm{Cl}]$ & $2.1[0.56,7.96]$ & $1.08[0.8,1.46]$ & $1.93[0.89,4.17]$ & $1.43[0.38,5.44]$ \\
\hline
\end{tabular}


Table 8 | Level 2 evidence of incidence of extrapyramidal symptoms with aripiprazole in patients with schizophrenia or schizoaffective disorder

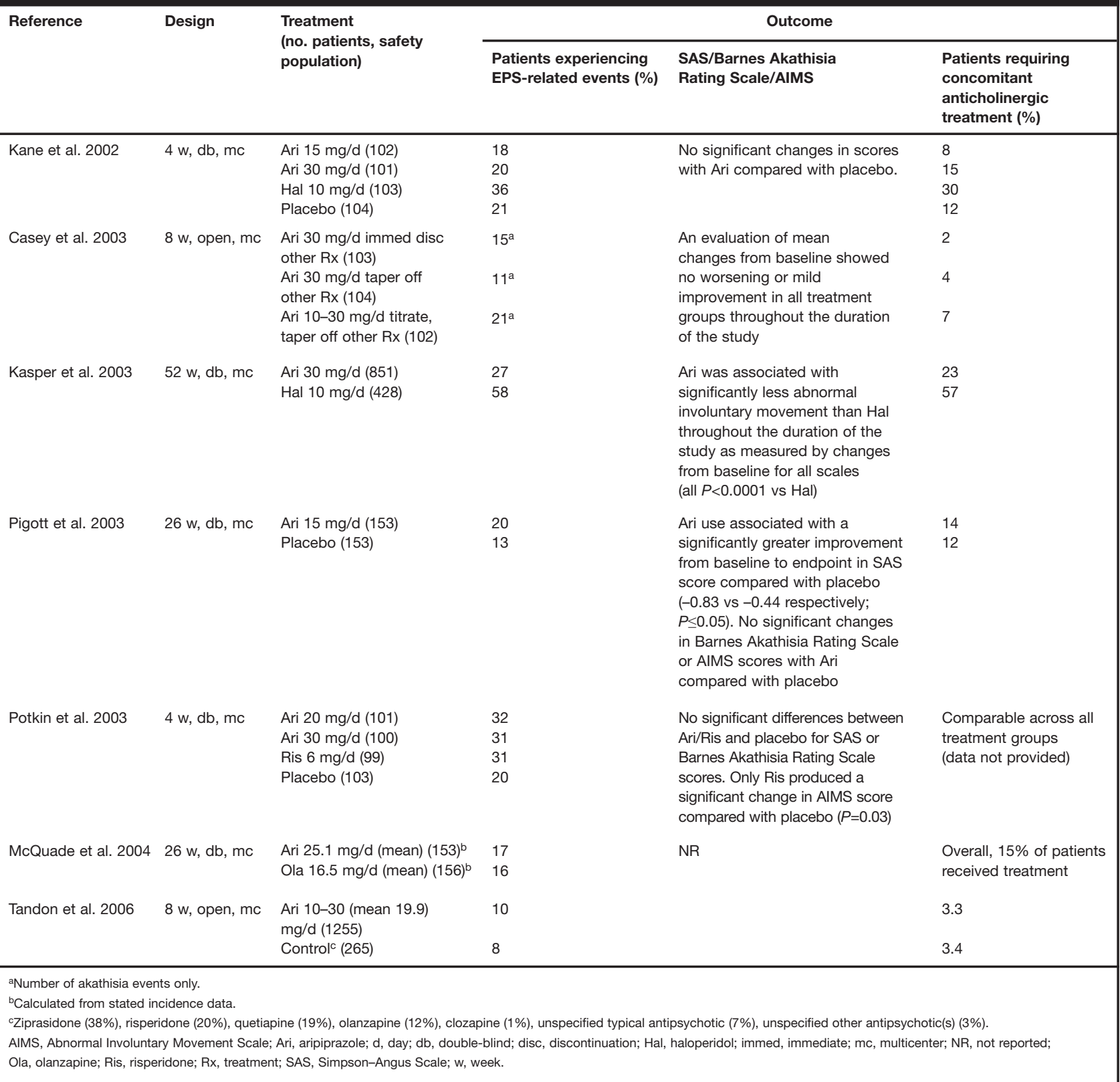

In longer-term studies, psychosis, akathisia, tremor, and somnolence do appear as common adverse effects (Kasper et al. 2003; Pigott et al. 2003; McQuade et al. 2004), suggesting that evidence from long-term clinical use of aripiprazole would be welcome, including the potential for development of tardive dyskinesia. The issue of akathisia is interesting since, although reported in long-term studies, akathisia or agitation may also occur after short-term use of aripiprazole (Möller, personal communication).

\section{Metabolic risk}

Level 1 and 2 evidence indicates that aripiprazole was more frequently associated with weight gain than placebo, but not to a significant extent (Table 9) (El-Sayeh \& Morganti 2004). Compared with placebo, aripiprazole was not associated with any clinically significant change in fasting glucose, glycosylated hemoglobin, total low-density lipoprotein (LDL) and high-density lipoprotein (HDL) cholesterol, and triglycerides (Pigott et al. 2003; El-Sayeh \& Morganti 2004). 
Table 9 | Level 2 evidence of the changes in body weight and serum prolactin levels with aripiprazole in patients with schizophrenia or schizoaffective disorder

\begin{tabular}{|c|c|c|c|c|c|c|}
\hline \multirow[t]{2}{*}{ Reference } & \multirow[t]{2}{*}{ Design } & \multirow{2}{*}{$\begin{array}{l}\text { Treatment } \\
\text { (no. patients, } \\
\text { safety population) }\end{array}$} & \multicolumn{4}{|c|}{ Outcome } \\
\hline & & & $\begin{array}{l}\text { Mean change from } \\
\text { baseline in body } \\
\text { weight }(\mathrm{kg})\end{array}$ & $\begin{array}{l}\text { Percentage of patients } \\
\text { with significant weight } \\
\text { gain at endpoint ( } \geq 7 \% \\
\text { increase from baseline) }\end{array}$ & $\begin{array}{l}\text { Mean change from } \\
\text { baseline in serum } \\
\text { prolactin levels } \\
(\mathrm{ng} / \mathrm{mL})\end{array}$ & $\begin{array}{c}\text { Patients with } \\
\text { prolactin levels } \\
\text { >ULN }\end{array}$ \\
\hline \multirow{4}{*}{$\begin{array}{l}\text { Kane et al. } \\
2002\end{array}$} & \multirow[t]{4}{*}{$4 \mathrm{w}, \mathrm{db}, \mathrm{mc}$} & Ari 15 mg/d (102) & +0.4 & $7 \%$ & -7.0 & NR \\
\hline & & Ari 30 mg/d (102) & +0.9 & $4 \%$ & -7.1 & NR \\
\hline & & Hal 10 mg/d (104) & +0.5 & $10 \%$ & +22.5 & NR \\
\hline & & Placebo (106) & +0.2 & $1 \%$ & -1.8 & NR \\
\hline \multirow[t]{3}{*}{$\begin{array}{l}\text { Casey et al. } \\
2003\end{array}$} & \multirow[t]{3}{*}{8 w, open, mc } & $\begin{array}{l}\text { Ari } 30 \text { mg/d immed } \\
\text { disc other } R x(103)\end{array}$ & -1.4 & $3 \%$ & -15.9 & 1 patient \\
\hline & & $\begin{array}{l}\text { Ari } 30 \mathrm{mg} / \mathrm{d} \text { taper } \\
\text { off other Rx (104) }\end{array}$ & -1.7 & $5 \%$ & -19.4 & 4 patients \\
\hline & & $\begin{array}{l}\text { Ari } 10-30 \mathrm{mg} / \mathrm{d} \\
\text { titrate, taper off } \\
\text { other } \mathrm{Rx}(102)\end{array}$ & -1.3 & $3 \%$ & -16.2 & 8 patients \\
\hline \multirow{2}{*}{$\begin{array}{l}\text { Kasper et al. } \\
2003\end{array}$} & \multirow[t]{2}{*}{$52 \mathrm{w}, \mathrm{db}, \mathrm{mc}$} & Ari 30 mg/d (839) & +1.05 & NR & $-8.1(\mathrm{n}=96)^{\mathrm{a}}$ & $3.4 \%(n=96)^{a}$ \\
\hline & & Hal 10 mg/d (425) & +0.39 & NR & $+34.2(\mathrm{n}=46)^{\mathrm{a}}$ & $61 \%(n=46)^{a}$ \\
\hline \multirow{2}{*}{$\begin{array}{l}\text { Pigott et al. } \\
2003\end{array}$} & \multirow[t]{2}{*}{$26 \mathrm{w}, \mathrm{db}, \mathrm{mc}$} & Ari 15 mg/d (151) & -1.26 & $6 \%$ & -21 & $5 \%$ \\
\hline & & Placebo (151) & -0.87 & $4 \%$ & -13 & $13 \%$ \\
\hline \multirow{4}{*}{$\begin{array}{l}\text { Potkin et al. } \\
2003\end{array}$} & \multirow[t]{4}{*}{$4 \mathrm{w}, \mathrm{db}, \mathrm{mc}$} & Ari 20 mg/d (101) & +1.2 & $13 \%$ & -6.6 & $4.1 \%$ \\
\hline & & Ari 30 mg/d (101) & +0.8 & $9 \%$ & -6.4 & $3.3 \%$ \\
\hline & & Ris 6 mg/d (99) & +1.5 & $11 \%$ & +47.9 & $90.5 \%$ \\
\hline & & Placebo (103) & -0.3 & $2 \%$ & +0.1 & $10.3 \%$ \\
\hline \multirow[t]{2}{*}{$\begin{array}{l}\text { McQuade et al. } \\
2004\end{array}$} & \multirow[t]{2}{*}{$26 \mathrm{w}, \mathrm{db}, \mathrm{mc}$} & $\begin{array}{l}\text { Ari } 25.1 \mathrm{mg} / \mathrm{d} \\
\text { (mean) (154) }\end{array}$ & -1.37 & $13 \%$ & NR & $8 \%$ \\
\hline & & $\begin{array}{l}\text { Ola } 16.5 \mathrm{mg} / \mathrm{d} \\
\text { (mean) }(155)\end{array}$ & +4.23 & $33 \%$ & NR & $37 \%$ \\
\hline $\begin{array}{l}\text { aSerum prolactin le } \\
\text { bFor patients with p } \\
\text { Ari, aripiprazole; d, } \\
\text { ULN, upper limit of }\end{array}$ & $\begin{array}{l}\text { Is were only colle } \\
\text { lactin levels with } \\
\text { ay; db, double-bl } \\
\text { ormal; w, week. }\end{array}$ & $\begin{array}{l}\text { d in the first (USA study } \\
\text { LN at baseline only. } \\
\text { disc, discontinued; Hal }\end{array}$ & $\begin{array}{l}\text { he two combined stud } \\
\text { peridol; immed, imme }\end{array}$ & mc, multicenter; NR, not rep & a, olanzapine; Ris, rispe & , treatment; \\
\hline
\end{tabular}

The incidence of weight gain was lower with aripiprazole and haloperidol in a 4-week study (Kane et al. 2002), although over 52 weeks the mean change in body weight was greater (not significant) following aripiprazole $30 \mathrm{mg} /$ day compared with haloperidol $10 \mathrm{mg} /$ day (Kasper et al. 2003). Aripiprazole was associated with a significantly greater increase in weight gain compared with haloperidol in patients with the lowest body mass index $\left(<23 \mathrm{~kg} / \mathrm{m}^{2}\right)$.

Body weight gain was comparable in patients receiving aripiprazole 20 or $30 \mathrm{mg} /$ day or risperidone $6 \mathrm{mg} /$ day after 4 weeks (Potkin et al. 2003). However, a 26-week RCT by McQuade et al. (2004) showed that by the end of the trial, $37 \%$ of patients with acute relapse treated with a mean dose of olanzapine $16.5 \mathrm{mg} /$ day $(n=161)$ experienced significant weight gain compared with $14 \%$ of those treated with a mean dose of aripiprazole $25.1 \mathrm{mg} /$ day $(P<0.001)(n=156)$. This observation is further supported by a meta analysis showing that aripiprazole, amisulpride, and ziprasidone were associated with only modest weight gain $(<2 \mathrm{~kg})$, while olanzapine was associated with clinically significant weight increases (4-10 kg) (Newcomer 2004), and by a short retrospective study on 10 elderly patients (Madhusoodanan et al. 2004).
After 26 weeks, triglyceride $(P<0.05)$, total cholesterol, and LDL cholesterol levels were lower in patients receiving aripiprazole 15-30 mg/day compared with those receiving olanzapine 10-20 mg/day, and HDL cholesterols were higher $(P<0.05)$ (McQuade et al. 2004). Significantly fewer of the aripiprazole group had clinically significant dyslipidemias compared with the olanzapine group $(P<0.05)$.

A further case-control study indicated that aripiprazole-treated patients had a similar risk of developing hyperlipidemia compared with patients treated with conventional antipsychotics [odds ratio (OR) 0.80 ; 95\% Cl 0.60, 1.07] or with ziprasidone (OR 0.97; $95 \% \mathrm{Cl} 0.84,1.12$ ) (Olfson et al. 2005a). In contrast, clozapine, quetiapine, risiperidone, and olanzapine were each associated with a significantly greater risk of hyperlipidemia compared with conventional agents.

There has recently been some discussion about an increased risk of cerebrovascular adverse events with atypical antipsychotics in elderly patients with dementia-related psychosis (Schneider et al. 2005). In February 2005, the US prescribing information for aripiprazole added a warning of the possibility of increased 
cerebrovascular risk in these patients (Anon. 2005). Level 1 evidence from a meta analysis indicates an OR of $1.73(95 \% \mathrm{Cl} 0.7,4.3)$ and RR 1.99 (95\% Cl 0.86, 4.62) for death with aripiprazole in patients with dementia (Schneider et al. 2005). In this patient population, the small increased risk associated with aripiprazole treatment of 8-12 weeks is in common with the other atypical antipsychotic drugs olanzapine, quetiapine, and risperidone.

\section{Prolactin levels}

There is consistent level 2 evidence that aripiprazole is associated with decreases in prolactin levels, in contrast to haloperidol, risperidone, and olanzapine, all of which were associated with increases (Table 9).

\section{QTC interval}

A 20-day, placebo-controlled, double-blind study in 50 healthy male volunteers revealed that aripiprazole $5-30 \mathrm{mg} /$ day induced no clinically significant changes in QTc (Mallikaarjun et al. 2004).

In patients with schizophrenia and schizoaffective disorder, Potkin et al. (2003) found mean changes in QTc interval of $+0.97,-2.35$, -2.18 , and $+6.31 \mathrm{msec}$ with aripiprazole $20 \mathrm{mg} /$ day, aripiprazole $30 \mathrm{mg} /$ day, placebo, and risperidone $6 \mathrm{mg} /$ day, respectively. A clinically significant increase in QTc interval (QTc of $\geq 450 \mathrm{msec}$ and $\geq 10 \%$ increase from baseline) occurred in three of the 95 risperidone recipients, but not in any other group.

\section{Switching to aripiprazole from other antipsychotic agents}

According to Casey et al. (2003), switching antipsychotic medications can lead to tolerability problems. In an 8-week, randomized, open-label RCT three possible strategies were adopted to switch 311 patients to aripiprazole $30 \mathrm{mg} /$ day from typical antipsychotics (haloperidol or thioridazine) or atypical antipsychotics (risiperidone or olanzapine). The switching process was safe and well tolerated whether patients were switched immediately to aripiprazole with immediate discontinuation of the previous antipsychotic, switched immediately to aripiprazole while tapering off the previous antipsychotic over a 2-week period, or tapered gradually onto aripiprazole while tapering off the previous antipsychotic over 2 weeks (Casey et al. 2003). After 8 weeks, patients switched to aripiprazole showed improvements in EPS, reductions in prolactin levels and weight, and significant improvements in PANSS scores. Nevertheless, there is some conflicting evidence from a case series report that four patients switched to aripiprazole 15-30 mg/day experienced worsening of psychosis which improved in two of the patients when aripiprazole therapy was discontinued (Ramaswamy et al. 2004).

\section{Quality of life}

Although quality of life is important for patients with schizophrenia, it is difficult to determine due to the fact that it relies on patient perception and self-evaluation, which is likely to be impaired by the underlying condition.
Evidence on the effect of aripiprazole on quality of life is limited. Unpublished data from an RCT reported in the systematic review by El-Sayeh and Morganti (2004) revealed no conclusive evidence of a clinically important improvement in quality of life among 154 patients given aripiprazole, as assessed by the Quality of Life Scale, a measure specific for schizophrenic deficit syndrome or enduring negative symptoms.

A prospective, multicenter, randomized, open-label study provides stronger evidence for a beneficial effect of aripiprazole on quality of life (Tandon et al. 2006). Approximately $71 \%$ of 1214 evaluable patients receiving a mean dose of aripiprazole $19.9 \mathrm{mg} /$ day, and $60 \%$ of their caregivers rated the drug as better or much better than prestudy medication, compared with $49 \%$ of patients and $38 \%$ of caregivers in the active control group.

Further evidence for a positive effect of aripiprazole on quality of life comes from an abstract report of an open-label, prospective, randomized study in 1119 outpatients with schizophrenia who switched to aripiprazole or another antipsychotic (olanzapine, risperidone, quetiapine, ziprasidone, or unspecified) (Carson et al. 2004). Using a 5-point scale, $60 \%$ of patients previously on ziprasidone, $53 \%$ on an unspecificied typical antipsychotic, 50\% on olanzapine, $49 \%$ on quetiapine, $49 \%$ on more than one other antipsychotic, and $48 \%$ on risperidone preferred aripiprazole. Between 34 and $45 \%$ of caregivers classified aripiprazole as "much better" than the previous medication.

\section{Economic evidence}

No formal studies on the cost effectiveness of aripiprazole have been reported. However, although doses compared did not imply therapeutic equivalence, cost comparisons in the UK conducted in 2004 revealed that the cost for 28 days' treatment with aripiprazole 10 or $15 \mathrm{mg} /$ day (£101.63) was approximately the same as olanzapine $10 \mathrm{mg} /$ day (£97.56), and risperidone 6 mg/day (£109.20) (Anon. 2004a; Chapman 2004). Aripiprazole $30 \mathrm{mg} /$ day costs $£ 203.26$ for 28 days, comparable to the $£ 195.11$ for olanzapine 20 mg/day (Anon. 2004a). Twenty-eight days' treatment with haloperidol 10 or $20 \mathrm{mg} /$ day costs up to $£ 11.99$ (Anon. 2004a), or £86-156 for 1 year (Anon. 2004b).

\section{Resource utilization}

Despite the higher acquisition cost of aripiprazole compared with haloperidol, this might be offset by the reduced discontinuation (Olfson et al. 2005b) and hospitalization rates (Carrigan et al. 2005), and better tolerability. Indeed, NICE guidance in England and Wales recommending the first-line use of atypical antipsychotics to manage schizophrenia in various primary and secondary care settings recognized the overall indirect cost benefits (e.g. more patients living independently and returning to work) and better tolerability compared with typical antipsychotics (NICE 2002a,b). NICE reported an estimated average cost saving of $£ 1000$ ( $£ 250-5000)$ per patient year in switching to atypical antipsychotics (NICE 2002a), and although aripiprazole was not available in the UK at the time guidance was issued, the clinical evidence suggest that it too could result in similar cost savings. 


\section{Patient group/population}

Studies to date suggest that atypical agents such as aripiprazole should be considered as first-line treatment of choice for patients newly diagnosed with schizophrenia or for patients suffering unacceptable adverse events with conventional agents (NICE 2002a; Chapman 2004). Switching to aripiprazole from other atypical antipsychotic drugs or from conventional antipsychotics appears to be well tolerated in most cases (Casey et al. 2003). The choice of which atypical antipsychotic depends on local acquisition costs, and on individual response and tolerability to other agents. Specific consensus guidelines for the use of aripiprazole in schizophrenia have recently been published by the Schizophrenia Innovation Working Group in the UK (Travis et al. 2005). They suggest that in comparison with other available antipsychotics, aripiprazole may be a useful alternative for patients for whom weight gain, EPS, and sedation are barriers to long-term treatment. Prescribing information carries a warning of increased cerebrovascular events in elderly patients with dementia-related psychosis (Anon. 2005).

\section{Dosage, administration, and formulations}

Aripiprazole (Abilify ${ }^{\circledR}$, Bristol-Myers Squibb) is available as 2, 5, 10,20 , and $30 \mathrm{mg}$ tablets and as a $1 \mathrm{mg} / \mathrm{mL}$ solution for oral administration. The recommended starting dose is 10 or $15 \mathrm{mg}$ once daily, with maintenance of $15 \mathrm{mg} /$ day; dosage should not be increased in the first 2 weeks of treatment, and the maximum recommended daily dose is $30 \mathrm{mg}$ (Anon. 2005). Dosage adjustment is not required in patients with impaired renal or hepatic function.

\section{Clinical value}

Atypical antipsychotics are now recommended as first-line agents for the treatment of patients with schizophrenia. Aripiprazole is a recent addition to the available atypical antipsychotics.

There is evidence that aripiprazole is at least as effective as haloperidol against the positive and negative symptoms of schizophrenia (Kane et al. 2002; Kasper et al. 2003), more effective in ameliorating the associated mood symptoms (Kasper et al. 2003), and is associated with a lower incidence of adverse events, particularly EPS. Aripiprazole also appears as effective as other atypical antipsychotics in the treatment of the positive and negative symptoms of schizophrenia. It has a relatively benign adverse event profile, comparable to that of other atypical antipsychotics. Importantly, aripiprazole is not associated with an increased risk of weight gain, metabolic disturbances, or increases in prolactin levels. This favorable tolerability profile may enhance compliance. Further observational studies, and evidence on cost effectiveness and resource utilization, and on the patientoriented outcomes of quality of life, general functioning, and satisfaction with treatment would help with defining the place in therapy of aripiprazole (El-Sayeh \& Morganti 2004), especially compared with other atypical antipsychotics. Also, although EPS is less common with aripiprazole, tremor and akathisia have been reported in longer-term studies (Kasper et al. 2003; Pigott et al.
2003; McQuade et al. 2004), suggesting a need for more evidence from long-term clinical use on the potential for development of tardive dyskinesia with aripiprazole.

Another issue of particular interest is that of treatment resistance. This remains a major unmet need, with clozapine being the only option despite its poor tolerability profile. There is no evidence that aripiprazole is effective in treatment-resistant patients. Interestingly, however, despite substantial numbers of patients leaving trials, fewer patients on aripiprazole discontinued treatment compared with other antipsychotics, either due to insufficient clinical response, worsening of illness, or adverse effects. Not only were discontinuation rates lower for aripiprazole in controlled trials, where treatment-resistant patients were excluded, but also in observational studies. A recent large-scale prospective effectiveness study in general psychiatry outpatient practice settings confirmed this finding, with a lower proportion of discontinuations among aripiprazole recipients than with active controls (Tandon et al. 2006). This is a telling observation, as these data may be more relevant to real-life clinical settings.

In conclusion, aripiprazole is an effective atypical antipsychotic and therefore may be considered as a first-line agent. It may have particular utility where tolerability is an issue, and may have particular benefit in patients with mood-associated or negative symptoms.

\section{References}

Anon. New drug evaluation: aripiprazole. Newcastle-upon-Tyne: Regional Drug and Therapeutics Centre; July 2004a. Available at:

http://www.nyrdtc.nhs.uk/docs/nde/NDE_62_aripiprazole.pdf (accessed October 21, 2005).

Anon. Aripiprazole (Abilify ${ }^{\circledR}$ ) for the treatment of schizophrenia. Staffordshire: Midland Therapeutic Review \& Advisory Committee; Oct 2004b. Available at: http://www.keele.ac.uk/depts/mm/MTRAC/ProductInfo/verdicts/A/aripiprazole.p df (accessed October 21, 2005).

Anon. Abilify US Prescribing Information. Available at: www.abilify.com (accessed October 21, 2005).

Burris KD, Molski TF, Xu C, et al. Aripiprazole, a novel antipsychotic, is a high-affinity partial agonist at human dopamine D2 receptors. $J$ Pharmacol Exp Ther. 2002;302:381-389.

Carrigan G, Cislo P, Ray S, et al. Risk of rehospitalization in antipsychotictreated patients. Abstract presented at: 158th Annual Meeting of the American Psychiatric Association; May 21-26, 2005; Atlanta, GA. Abstract NR178.

Carson WH, Archibald DG Manos G, et al. Short-term efficacy of aripiprazole on depression and anxiety in schizophrenia. Abstract presented at: 156th Annual Meeting of the American Psychiatric Association; May 17-22, 2003; San Francisco, CA. Abstract NR549.

Carson W, Marcus R, Jody D, et al. The effectiveness of switch to aripiprazole stratified by prior antipsychotic. Poster presented at: 157th Annual Meeting of the American Psychiatric Association; May 1-6, 2004; New York, NY.

Casey DE, Carson WH, Saha AR. Switching patients to aripiprazole from other antipsychotic agents: a multicenter randomized study. Psychopharmacology. 2003;166:391-399.

Chapman V. New medicines profile: aripiprazole. Leicester: UK Medicines Information Service; 2004. Available at:

http://www.ukmi.nhs.uk/NewMaterial/html/docs/AripiprazoleNMP0604.pdf (accessed October 21, 2005).

Clark R. Disease overview - schizophrenia. Drugs in Context. 2005;1:92-100. Cooper-Casey K, Mesen-Fairnardi A, Galke-Rollins B, et al. Suggestive linkage of schizophrenia to 5p13 in Costa Rica. Mol Psychiatry. 2005;10:651-656.

El-Sayeh HG, Morganti C. Aripiprazole for schizophrenia (review). Cochrane Database Syst Rev. 2004;(2):CD004578.pub2. 
Falkai P, Wobrock T, Liebermann J, et al. World Federation of Societies of Biological Psychiatry (WFSBP) guidelines for biological treatment of schizophrenia. Part 1: acute treatment of schizophrenia. World Journal Biol Psych. 2005;6:132-191.

Folsom DP, Jeste DV. Schizophrenia in homeless persons: a systematic review of the literature. Acta Pyschiatr Scand. 2002;105:404-413.

Folsom DP, Hawthorne W, Lindamer L, et al. Prevalence and risk factors for homelessness and utilization of mental health services among 10,340 patients with serious mental illness in a large public mental health system. Am J Psychiatry. 2005;162:370-376.

Gilmer TP, Folsom DP, Hawthorne W, et al. Assisted living and use of health services among Medicaid beneficiaries with schizophrenia. $J$ Ment Health Policy Econ. 2003;6:59-65.

Jordan S, Koprivica V, Chen R, et al. The antipsychotic aripiprazole is a potent, partial agonist at the human 5- $\mathrm{HT}_{1 \mathrm{~A}}$ receptor. Eur J Pharmacol. 2002;441:137-140.

Kandel ER. Disorders of thought and volition: schizophrenia. In: Kandel ER, Schwartz JA, Jessell TM, editors. Principles of neural science. 4th ed. New York: McGraw-Hill; 2000. pp. 1188-1208.

Kane JM, Carson WH, Saha AR, et al. Efficacy and safety of aripiprazole and haloperidol versus placebo in patients with schizophrenia and schizoaffective disorder. J Clin Psychiatry. 2002;63:763-771.

Kasper S, Lerman MN, McQuade RD, et al. Efficacy and safety of aripiprazole vs. haloperidol for long-term maintenance treatment following acute relapse of schizophrenia. Neuropsychopharmacology. 2003;6:325-337.

Kelly DL, Conley RR. Sexuality and schizophrenia. Schizophrenia Bull. 2004;30:767-779.

Kemmler G, Hummer M, Widschwendter C, Fleischhacker W. Dropout rates in placebo-controlled and active-controlled trials of antipsychotic drugs: a metaanalysis. Arch Gen Psychiatry. 2005;62:1305-1312.

Launer M. Partial dopamine agonists in schizophrenia. Hospital Med. 2005;66:300-303.

Lehman AF, Lieberman JA, Dixon LB, et al. Practice guideline for the treatment of patients with schizophrenia, second edition.

2004;161(Suppl.):1-56.

Lewis DA, Lieberman JA. Catching up on schizophrenia: natural history and neurobiology. Neuron. 2000;28:325-334.

Liberty IF, Todder D, Umansky R, Harman-Boehm I. Atypical antipsychotics and diabetes mellitus: an association. IMAJ. 2004;6:276-279.

Lieberman JA. Dopamine partial agonists. A new class of antipsychotic. CNS Drugs. 2004;18:251-267.

Lieberman JA, Mailman RB, Duncan G, et al. Serotonergic basis of antipsychotic drug effects in schizophrenia. Biol Psychiatry.

1998;44:1099-1117.

Lieberman JA, Perkins D, Belger A, et al. The early stages of schizophrenia: speculations on pathogenesis, pathophysiology, and therapeutic approaches. Biol Psychiatry. 2001;50:884-897.

Lien L. Economic factors influencing the implementation of community care for severely ill schizophrenic patients. World Hosp Health Serv. 2005;41:21-24.

Lindamer AL, Bailey A, Hawthorne W, et al. Gender differences in characteristics and service use of public mental health patients with schizophrenia. Psychiatr Serv. 2003;54:1407-1409.

Lowyck B, De Hert M, Peeters E, et al. A study of the family burden of 150 family members of schizophrenic patients. Eur Psychiatry. 2004;19:395-401.

Lublin $\mathrm{H}$, Eberhard $\mathrm{J}$, Levander $\mathrm{S}$. Current therapy issues and unmet clinical needs in the treatment of schizophrenia: a review of the new generation of antipsychotics. Int Clin Psychopharmacol. 2005;20:183-198.

Madhusoodanan S, Brenner R, Gupta S, et al. Clinical experience with aripiprazole treatment in ten elderly patients with schizophrenia or schizoaffective disorder: retrospective case studies. CNS Spectr. 2004;9:862-867.

Mallikaarjun S, Salazar DE, Braner SL. Pharmacokinetics, tolerability, and safety of aripiprazole following multiple oral dosing in normal healthy volunteers. J Clin Pharmacol. 2004;44:179-187.

Marder SR, McQuade RD, Stock E, et al. Aripiprazole in the treatment of schizophrenia: safety and tolerability in short-term, placebo-controlled trials. Schizophrenia Res. 2003;61:123-136.
McQuade RD, Stock E Marcus R, et al. A comparison with weight change during treatment with olanzapine or aripiprazole. J Clin Psychiatry. 2004;65(Suppl.18):47-56.

Mortimer A. Antipsychotic treatment in schizophrenia: atypical options and NICE guidelines. Eur Psychiatry. 2003;18:209-219.

Newcomer JW. Metabolic risk of antipsychotic treatment. Clin Ther. 2004;2:1936-1946.

NICE (National Institute for Health and Clinical Excellence). Guidance on the use of newer (atypical) antipsychotic drugs for the treatment of schizophrenia. Technology appraisal guidance No. 43. London: NICE; 2002a. Available at: http://www.nice.org.uk (accessed October 21, 2005).

NICE (National Institute for Health and Clinical Excellence). Schizophrenia. Core interventions in the treatment and management of schizophrenia in primary and secondary care. Clinical guideline 1. London: NICE; 2002b. Available at: http://www.nice.org.uk (accessed October 21, 2005).

Ohlsen RI, Pilowsky LS. The place of partial agonism in psychiatry: recent developments. J Psychopharmacol. 2005;19:408-413.

Olfson M, Corey-Lisle PK, Marcus S, et al. Hyperlipidemia following treatment with antipsychotic medications. Abstract presented at: 158th Annual Meeting of the American Psychiatric Association; May 21-26, 2005a. Abstract NR175.

Olfson M, Carrigan G, Corey-Lisle PK, Cislo P, Ray S. Discontinuation rates among treated schizophrenia patients in managed care. Abstract presented at: 158th Annual Meeting of the American Psychiatric Association; May 21-26, 2005b. Abstract NR174.

Owen MJ, O'Donovan MC, Harrison PJ. Schizophrenia: a genetic disorder of the synapse. BMJ. 2005;330:158-159.

Pigott TA, Carson WH, Saha AR. Aripiprazole for the prevention of relapse in stabilized patients with chronic schizophrenia: a placebo-controlled 26-week study. J Clin Psychiatry. 2003;64:1048-1056.

Potkin SG, Saha AR, Kujawa MJ, et al. Aripiprazole, an antipsychotic with a novel mechanism of action, and risiperidone vs placebo in patients with schizophrenia and schizoaffective disorder. Arch Gen Psychiatry. 2003;60:681-690.

Ramaswamy S, Vijay D, William M, et al. Aripiprazole possibly worsens psychosis. Int Clin Psychopharmacol. 2004;19:45-48.

RANZCP (Royal Australian and New Zealand College of Psychiatrists). Royal Australian and New Zealand College of Psychiatrists clinical practice guidelines for the treatment of schizophrenia and related disorders. Aust NZ J Psychiatry. 2005;39:1-30.

Schneider LS, Dagerman KS, Insel P. Risk of death with atypical antipsychotic drug treatment for dementia. JAMA. 2005;294:1934-1943.

Shapiro DA, Renock S, Arrington E, et al. Aripiprazole, a novel atypical antipsychotic drug with a unique and robust pharmacology. Neuropsychopharmacol. 2003;28:1400-1411.

Tandon R, Marcus RN, Stock EG, et al. A prospective, multicenter, randomized, parallel-group, open-label study of aripiprazole in the management of patients with schizophrenia or schizoaffective disorder in general psychiatric practice: Broad Effectiveness Trial With Aripiprazole (BETA). Schizophrenia Res. 2006; 84:77-89.

Travis MJ, Burns T, Dursun S, et al. Aripiprazole in schizophrenia: consensus guidelines. Int J Clin Pract. 2005;59:485-495.

van Rijn S, Aleman A, Swaab H, Kahn RS. Neurobiology of emotion and high risk for schizophrenia: role of the amygdala and the X-chromosome. Neurosci Biobehav Rev. 2005;29:385-397.

Vantalon V, Briard-Luginbuhl V, Mouren MC. Fragile X syndrome and very early onset schizophrenia: a female case study (in French). Arch Pediatr. 2005;12:176-179.

Volavka J, Czobor P, Citrome L, et al. Efficacy of aripiprazole against hostility in schizophrenia and schizoaffective disorder: data from 5 double-blind studies. J Clin Psychiatry. 2005;66:1362-1366.

Correspondence: William Winlow, Core Medical Publishing, Mere House, Brook Street, Knutsford, Cheshire WA16 8GP, UK or at editor@coreevidence.com 